\title{
Expression of mesenchymal stem cell marker CD90 on dermal sheath cells of the anagen hair follicle in canine species
}

\author{
F. Mercati, L. Pascucci, P. Ceccarelli, C. Dall'Aglio, V. Pedini, A.M. Gargiulo \\ ${ }^{1}$ Dipartimento di Scienze Biopatologiche e Igiene delle Produzioni Animali e Alimentari, Sezione di \\ Anatomia Veterinaria, Perugia, Italy
}

\section{chtil}

(C)2009 European Journal of Histochemistry

The dermal sheath (DS) of the hair follicle is comprised by fibroblast-like cells and extends along the follicular epithelium, from the bulb up to the infundibulum. From this structure, cells with stem characteristics were isolated: they have a mesenchymal origin and express CD90 protein, a typical marker of mesenchymal stem cells. It is not yet really clear in which region of hair follicle these cells are located but some experimental evidence suggests that dermal stem cells are localized prevalently in the lower part of the anagen hair follicle.

As there are no data available regarding DS stem cells in dog species, we carried out a morphological analysis of the hair follicle DS and performed both an immunohistochemical and an immunocytochemical investigation to identify $\mathrm{CD}^{+} 0^{+}$cells. We immunohistochemically evidenced a clear and abundant positivity to CD90 protein in the DS cells located in the lower part of anagen hair follicle. The positive cells showed a typical fibroblast-like morphology. They were flat and elongated and inserted among bundles of collagen fibres. The whole structure formed a close and continuous sleeve around the anagen hair follicle. Our immunocytochemical study allowed us to localize CD90 protein at the cytoplasmic membrane level.

Key words: CD90, mesenchymal stem cells, hair follicle, dog.

Correspondence: Francesca Mercati,

Sezione di Anatomia Veterinaria, Dipartimento di Scienze Biopatologiche ed Igiene delle Produzioni Animali ed Alimentari, Via S.Costanzo 4, 06126 Perugia, Italy.

Tel.: +39.075.5857601.

Fax: +39.075.5857631.

E-mail: fmercati@yahoo.it

Paper accepted on July 22, 2009

European Journal of Histochemistry 2009; vol. 53 issue 3 (July-September): 159-166
T he hair follicle represents an important stem cell niche in the skin. It contains dermal and epithelial stem populations that display distinct properties and localization. While epithelial stem cells reside in the middle region of the hair follicle outer root sheath (Schneider et al., 2009; Lyle et al., 1998; Cotsarelis et al., 1990), dermal stem cells are located in the dermal sheath (DS) (Jahoda, 2003; Jahoda and Reynolds, 2001).

The dermal sheath, or fibrous root sheath, is a layer of dense connective tissue that extends along the hair follicle, from the bulb up to the infundibulum. In the anagen hair follicle, it is comprised of mesenchymal cells located among collagen and elastic fibres. The cells are flat and elongated while collagen fibres form a circular inner layer and a longitudinal outer layer in the lower part of hair follicle (VonTscharner and Suter, 1994; Jahoda et al., 1992). At the base of the hair follicle, the DS is connected to the dermal papilla (Scott et al., 2000). The basement membrane, or glassy membrane, separates the DS from the epithelial component of the hair follicle (Scott et al., 2000).

Follicular dermal stem cells have a mesenchymal origin and share many properties common to bone marrow-derived mesenchymal stem cells (MSCs) (Hoogduijn et al., 2006). They express the MSC cell-surface marker CD90, show a high colony forming unit ability and can differentiate into several mesenchymal lineages, such as osteoblasts, adipocytes, chondrocytes and myocytes (Hoogduijn et al., 2006; Jahoda et al., 2003). They also express neuroprogenitor markers (Hoogduijn et al., 2006) and, finally, they can repopulate the haematopoietic system (Lako et al., 2002). In the literature, we can find different information about stem cell localization: the whole dermal sheath, the peri-bulbar dermal sheath, the dermal papilla (Hoogduijn et al., 2006, McElwee et al., 2003, 
Gharzi et al., 2003, Jahoda et al., 2003.)

CD90 (Thy-1) is a small GPI-anchored protein localized in the outer leaflet of the cell membrane (Low and Kincade, 1985). This protein is present in a large number of tissues and cells, even if a great species variation has been described (Mansour Haeryfar, 2004; Tokugawa et al., 1997; McKenzle and Fabre, 1981). CD90 plays a role in cell-cell interaction events, including intracellular adhesion and cell recognition during development (Saalbach et al., 2000; Morris, 1985), and is considered an important stem cell marker; for this last reason it is commonly used to identify mesenchymal stem cells in vitro (Kern et al., 2007; Yoshimura et al., 2006; Le Blanc and Ringdén, 2006; Pittenger et al., 1999). Furthermore, it has been identified in other kinds of stem cells such as haematopoietic progenitor cells (Craig et al., 1993) and hepatic progenitor cells in the human fetal liver (Masson et al., 2006).

The hair follicle is the focus of increasing interest because it contains well defined stem cell populations that exhibit various developmental properties. We retain that in dogs, as already demonstrated in other species (Hoogduijn et al., 2006; Zhang et al., 2006; Jahoda et al., 2003; Lako et al., 2002), this organ may be a suitable and accessible source for both epithelial and mesenchymal stem cells that may be isolated and in vitro cultured. Since it is possible to take skin samples without injuring the patient, we chose the hair follicle to study and identify stem cells with the future purpose of using them in regenerative medicine.

Dogs are affected by several skin diseases and some of them may be related to alterations of somatic stem cells. We retain that the study of hair follicle stem cell biology may improve our knowledge of etiology and pathogenesis of these skin diseases.

In previous works we investigated the stem cells in dog hair follicles; we identified the location of putative epithelial stem cells at the isthmus and described the bulge-like region (Pascucci et al., 2006; Mercati et al., 2008). To the authors' knowledge, there are no data available neither concerning the localization of DS stem cells nor concerning the expression of CD90 in the hair follicle as regards the canine species. Therefore, in this study, we described the morphological characteristics of DS cells and examined the immunohis- tochemical localization of CD90 protein in dog hair follicles with both light and transmission electron microscopy. The aim of our study is to observe the dermal sheath cells encompassing the hair follicle and to determine where $\mathrm{CD} 90^{+}$cells reside. CD90 is one of the main markers used to identify mesenchymal stem cells and it has been observed in stem cells isolated from the dermal sheath of hair follicles (Hoogduijn et al., 2006). For this reason, we suppose that CD90 protein can help us to identify the hair follicle dermal stem compartment in dog.

\section{Materials and Methods}

\section{Sample collection}

Skin samples were obtained by excisional biopsy from the dorsal neck, from the cheek and from the abdominal region of healthy dogs; the skin was devoid of primary or secondary cutaneous lesions. Dogs of different breeds, but all characterized by a smooth coat, were selected: a Belgian shepherd, a Dalmatian, a Labrador retriever, a Border Collie, and three mixed breeds. Their ages ranged from 3 to 9 years.

\section{Basic histology}

The skin samples were fixed in a 10\% neutral buffered formalin solution, dehydrated in graded ethanol, cleared in xylene and embedded in paraffin wax. Five $\mu \mathrm{m}$ thick sections were processed for staining with haematoxylin and eosin and then observed under a light microscope.

\section{Ultrastructural studies}

Immediately after excisional biopsy, the tissue samples were fixed in $2.5 \%$ glutaraldehyde in $0.1 \mathrm{M}$ phosphate buffer ( $\mathrm{pH} 7.4$ ) for 4 hours at room temperature, and post-fixed in $2 \%$ osmium tetroxide in $0.1 \mathrm{M}$ phosphate buffer for 3 hours. Then, the specimens were dehydrated in graded ethanol, embedded in Epon 812 (Electron Microscopy Sciences) and cured at $60^{\circ} \mathrm{C}$ for 48 hours.

Semithin sections were cut for light microscope and stained with methylene blue in borax; $90 \mathrm{~nm}$ ultrathin sections were mounted on 200-mesh gold grids, counterstained with uranyl acetate and lead citrate and analyzed by a transmission electron microscope (Philips EM208). 


\section{Immunohistochemistry}

Sections processed as for basic histology were mounted on poly-L-lysine-coated slides and dried at $37^{\circ} \mathrm{C}$.

Immunohistochemistry was performed using standard techniques. In dewaxed sections the endogenous peroxidase activity was quenched with $10^{\prime}$ incubation in a peroxidase-blocking solution $\left(3 \% \mathrm{H}_{2} \mathrm{O}_{2}\right)$. Then, the sections were treated for 10 min with $0.05 \%$ trypsin solution for antigen retrieval and blocked with 1:10 normal goat serum for 30'. Subsequently, the sections were incubated with 1:100 mouse monoclonal antiCD90 antibody (VMRD) for 24 hours at room temperature and, then, with 1:200 goat antimouse biotin conjugate antibody (Zymed). The Vectastain $A B C$ kit (Vector Laboratories) and DAB cromogen (Dako Cytomation) were used to visualize the immunohistochemical reaction. Negative control sections were produced by omission of the primary antibody.

\section{Immunocytochemistry}

After fixation for 1 hour at room temperature in $4 \%$ paraformaldehyde and $0.1 \%$ glutaraldehyde buffered by $0.1 \mathrm{M}$ phosphate saline solution $(\mathrm{pH}$ 7.4), the specimens were dehydrated and embedded in Bioacryl resin (Bio-optica, Milano, Italy). Semithin sections ( $1 \mu \mathrm{m}$ thick) were stained with methylene blue in borax for light microscopic examination to identify the region of our interest. Ultrathin sections ( $90 \mathrm{~nm}$ ) were subsequently cut and mounted on parlodion-coated 200-mesh nickel grids (Sigma), treated with $1 \%$ BSA in $0.1 \mathrm{M}$ TBS $\mathrm{pH} 7.4$ for $5 \mathrm{~min}$ at room temperature and, then, incubated for $2 \mathrm{~h}$ at room temperature in a humid chamber with mouse monoclonal antiCD90 antibody (VMRD) diluted $1: 20$ in a solution of 0.1 M TBS containing 1\% BSA and $1 \%$ Normal Goat serum. After several washes in TBS to remove the excess antibody, the grids were incubated for $1 \mathrm{~h}$ at room temperature with goat antimouse antibody conjugated with $10 \mathrm{~nm}$ gold particles (Aurion) diluted $1: 40$ in $0.1 \mathrm{M} \mathrm{TBS} \mathrm{pH} 7.4$ plus $1 \%$ BSA. After several washes in TBS and counterstaining with uranyl acetate, the sections were examined with a Philips EM 208 transmission electron microscope.

Sections in which the primary antibody was omitted were used as negative control.

\section{Results}

\section{Morphological evaluation}

At the light microscopical level, we could describe the DS of the lower part of the anagen hair follicles as a thin layer closely adjacent to the outer root sheath (Figure 1a, 1c, 4a). It was rich in dermal flat cells with lengthened nuclei; the cells were arranged along the follicular wall in a parallel way. The DS appeared as a distinct and clearly recognizable structure because in the lower part of the hair follicle it was encompassed by adipocytes. In the medium and upper regions, the DS was contiguous with the dermis and the dermal cells seemed to be less numerous. In semithin sections, the DS cells were clearly recognizable as a continuous layer of flattened cells whose cytoplasm appeared as a slender and threadlike frame that exactly followed the epithelium profile (Figure 1a, 1c).

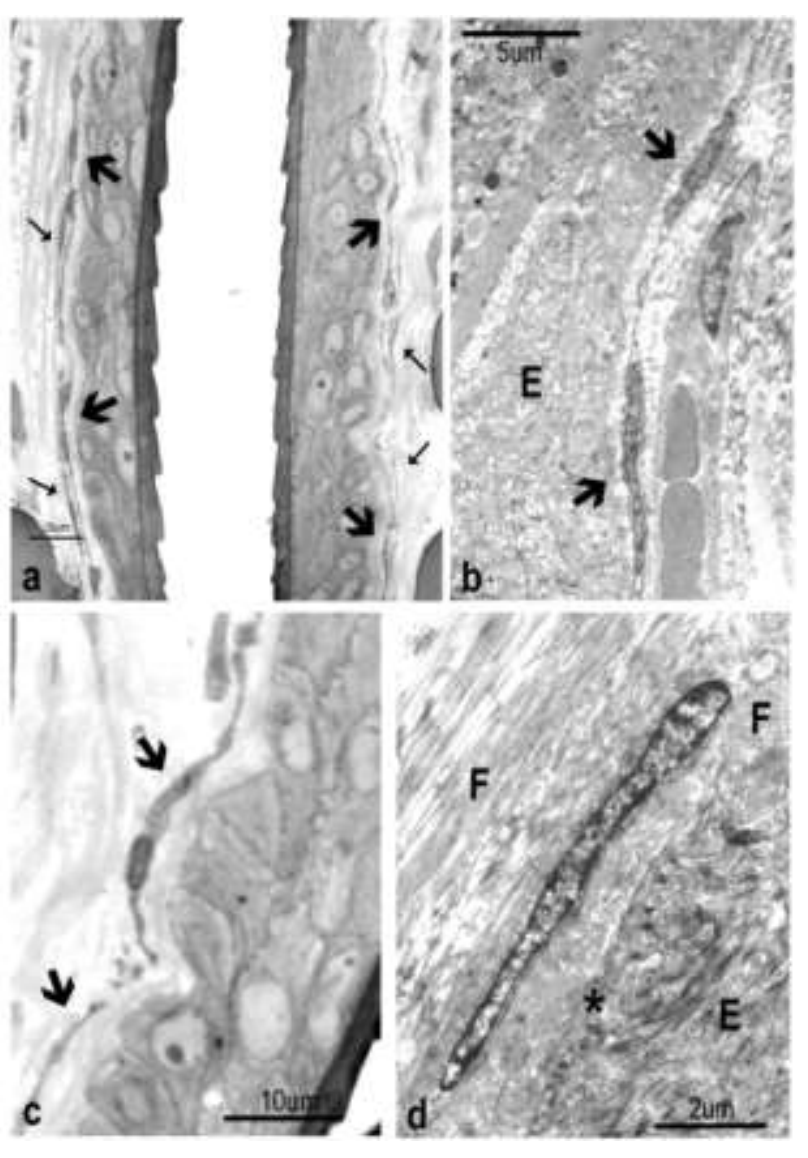

Figure 1. The soprabulbar and bulbar region of the anagen hair follicle. The dermal sheath cells are located all along the hair follicle, are very thin and flattened with elongated nuclei. The cytoplasm appears as a threadlike frame that occasionally overlaps among adjacent cells (thin arrow). Semithin (a-c) and ultrathin sections (b-d). Arrows = dermal sheath cells; $E=$ epithelial cells of the follicle; *basal membrane; F, collagen fibres. Bar $=10 \mu \mathrm{m}$ (a-c), $5 \mu \mathrm{m}$ (b), $2 \mu \mathrm{m}$ (d). 
Transmission electron microscopical observations showed that the DS consisted of a layer of fibrous connective tissue and a basal membrane in close apposition with the follicular epithelium (Figure $1 d, 2)$. In the connective tissue it was possible to recognize the dermal cells as being elongated and slender, flattened against the follicular epithelium and parallely aligned to the follicular wall (Figure 1b). The nuclei of the dermal cells appeared regular and elongated with a distinctive layer of marginal heterochromatin adjacent to the membrane (Figure $1 d, 2)$. The cells were comprised among bundles of collagen fibres that presented a circular and longitudinal arrangement; the circular layer was the nearest to the basal membrane (Figure $1 d$ ). The cytoplasm of dermal cells was very thin and attenuated (Figure 2). The cell processes were inserted among the fibres and it seemed that, as a whole, the cells formed an unbroken sleeve around the follicle. It was possible to observe a large number of hemidesmosomal junctions between the basal cells of the outer root sheath and the basal membrane.

\section{In situ expression of CD90 in the hair follicle der- mal sheath}

\section{Immunohistochemistry}

The immunohistochemical investigations, performed on the skin specimens, permitted us to evi-

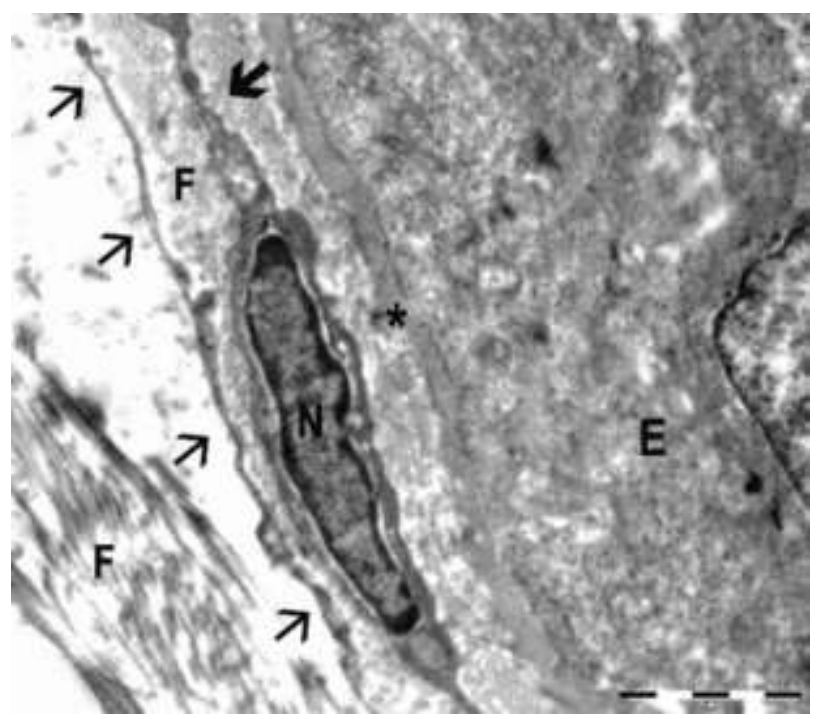

Figure 2. A dermal sheath cell extends along the hair follicle and is parallely aligned with the epithelium profile. It is possible to observe the thicker central part, where the nucleous $(\mathrm{N})$ is located, and the thinner peripherical part (big arrow). The thin arrows point to the threadlike cytoplasm of another cell that is located at the side. $E=$ epithelial cells of the follicle; *basal membrane; F, collagen fibres. Bar $=2 \mu \mathrm{m}$. dence the expression of CD90 antigen in the perifollicular DS (Figure 3). The $\mathrm{CD} 0^{+}$area was quite large with regard to the hair follicle extension (Figure $3 a$ ). This area appeared as a continuous line around the hair follicles (Figure $3 b, 3 c$ ), but only the bulbar and the soprabulbar regions were clearly encompassed by an intense staining. The reactivity sometimes stopped in a rather sharp way between the isthmic and the soprabulbar region; however, it sometimes seemed to involve the most prossimal part of the isthmus as well. We also observed some

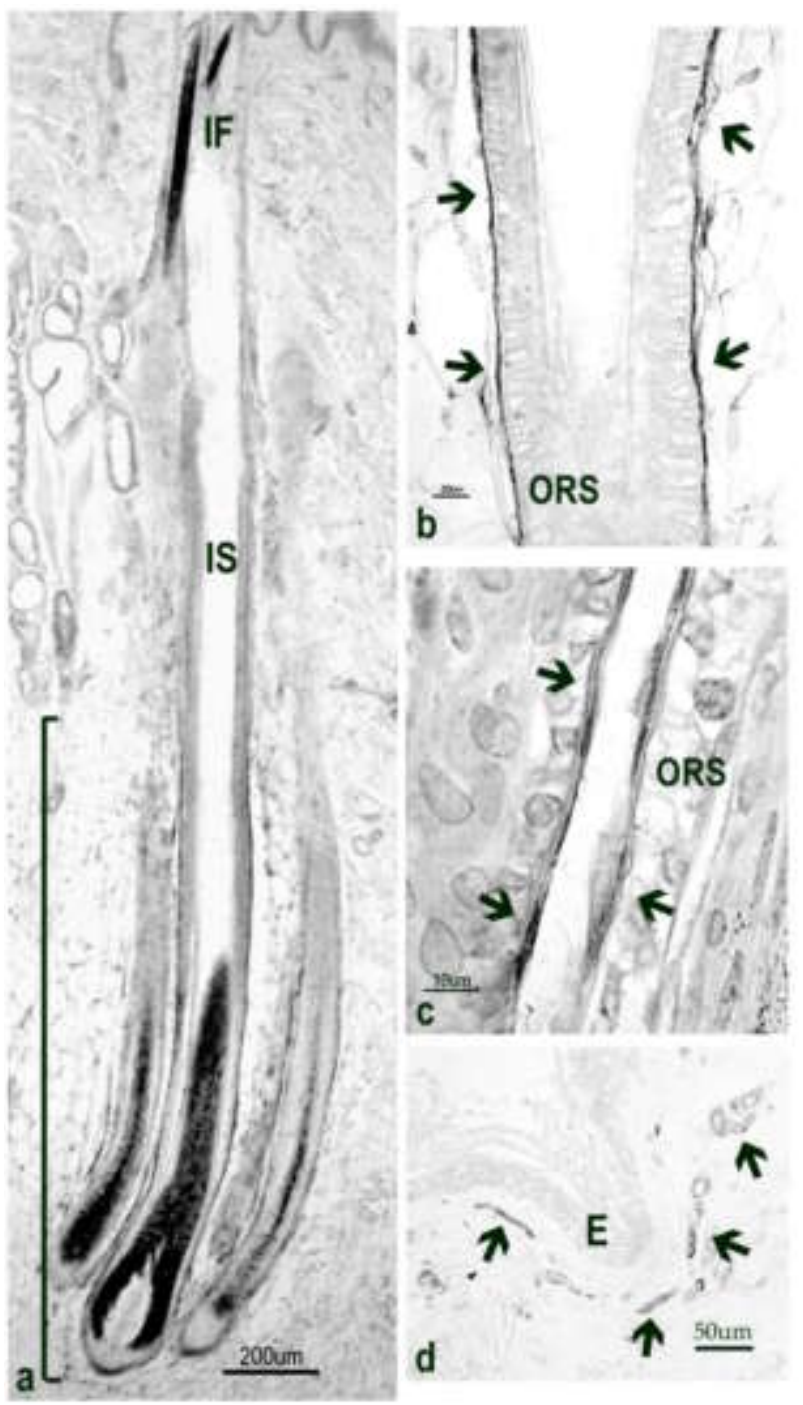

Figure 3. Immunohistochemical staining for CD90 protein. (a) An entire primary and two secondary hair follicles. The bulbs are well-developed and present the onion-shaped thickening typical of the anagen phase. The soprabulbar and the bulbar regions of all follicles are positively stained for CD90 protein (square bracket). (b-c) Soprabulbar region, higher magnification. The positive staining (arrows) appears as a sharp outline along the epithelium profile. (d) The microvessels below the epidermis are CD90 positive (arrows). Epidermis not stained. ORS, outer root sheath; E = epidermis; IF, infundibulum; IS, Isthmus. Bar =200 $\mu \mathrm{m}$ (a), $20 \mu \mathrm{m}$ (b), $10 \mu \mathrm{m}$ (c), $50 \mu \mathrm{m}$ (d). 
$\mathrm{CD}^{\circ} \mathrm{O}^{+}$mesenchymal cells around the bulb of anagen hair follicles but detached from the DS. The dermal papilla cells were negative to CD90 antibody (Figure 4b). All primary and secondary hair follicles showed clear immunohistochemical positivity (Figure 3a). No reaction for CD90 was detected in the epithelial structures of the skin, such as the follicular epithelium, the epidermis, sebaceous or sweat glands. The blood vessels scattered in the dermis appeared positive to CD90 (Figure 3d).

\section{Immunocytochemistry}

Immunocytochemical observations evidenced clusters of gold particles, localized at the level of

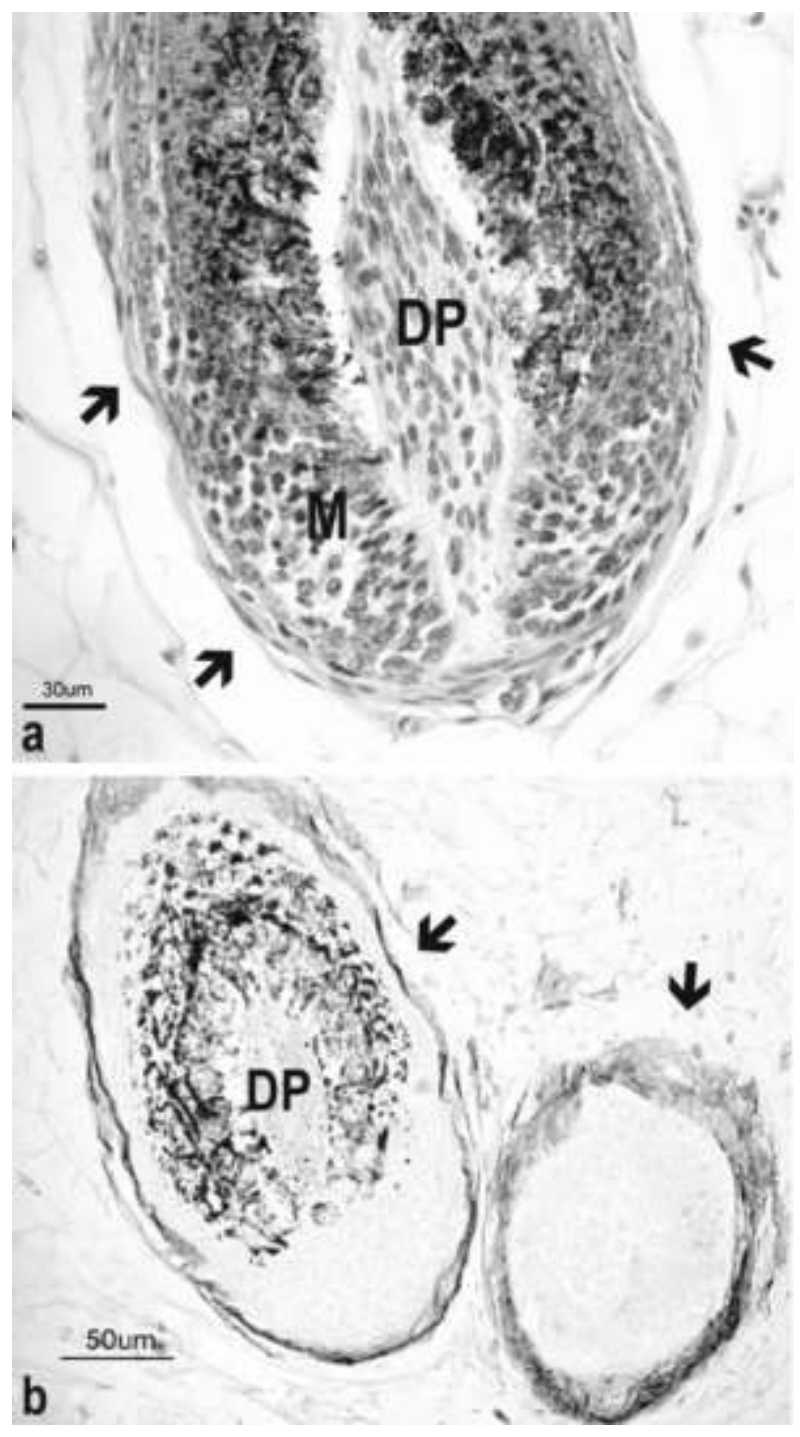

Figure 4. The bulb region. (a) Morphological features of anagen (H\&H). (b) Dermal sheath cells are clearly recognizable as a dark line around the bulb (CD90 immunohistochemical staining). Arrows = dermal sheath; DP, dermal papilla; M, matrix. Bar $=30$ $\mu \mathrm{m}$ (a), $50 \mu \mathrm{m}$ (b). the cytoplasmic membrane of DS cells (Figure 5). Positivity was not uniformly scattered along the membrane but showed a focal expression with a distribution all along the cell. We observed positivity in the lower regions of anagen hair follicles.

\section{Discussion}

Mesenchymal stem cells arouse great interest because of their potentiality in the treatment of several diseases in man as well as in domestic animals and, at the moment, it is possible to obtain these cells from a great range of tissutal source besides hair follicles (Kern et al., 2007; In't Anker et al., 2003; 0'Donoghue et al., 2003; Shi et al., 2003; Zuk et al., 2002; Erices et al., 2000). Each source presents some peculiar characteristics that distinguish it from others such as morphology, stem cell concentration, cell differentiation capacity, etc.

The dermal sheath surrounding the outer root sheath contains progenitor and stem cells, but it is

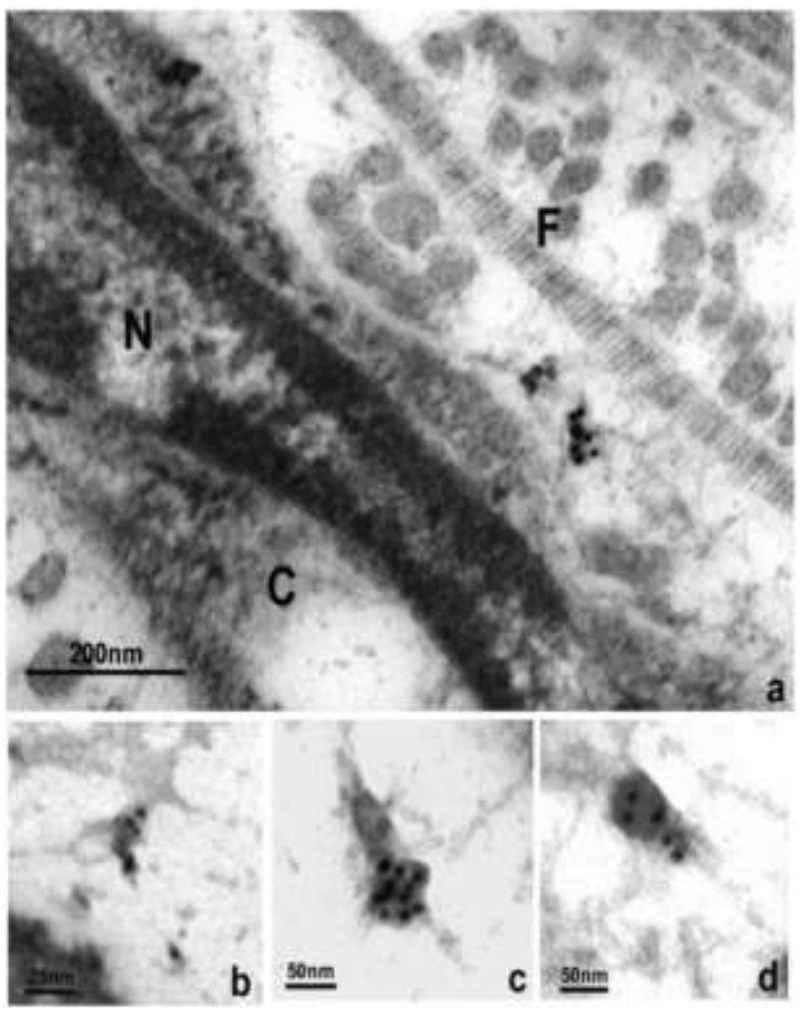

Figure 5. Immunocytochemical assay for CD90 protein. The colloidal gold particles are grouped in clusters and show a focal distribution along the cytoplasmic membrane. (a) A gold aggregate in the cell body and (b, c, d) in the cytoplasmic processes, higher magnifications. $C$, dermal sheath cell; $N$, nucleus; $F$, collagen fibres. Bar =200 nm (a), $25 \mathrm{~nm}$ (b), $50 \mathrm{~nm}$ (c-d). 
not yet really clear where these cell populations reside: on the basis of functional characteristics, it seems that these cells are localized in the lower part of hair follicles; nevertheless, it is also possible to obtain multipotent cells from every region of the hair follicle dermal sheath (Hoogduijn et al., 2006; McElwee et al., 2003; Jahoda et al., 2003; Lako et al., 2002).

Given the potentiality to use hair follicle stem cells in the therapy of some skin diseases, in this report we proposed an investigation regarding hair follicle dermal stem cells in dog species.

Dog coat is a mosaic comprised of primary and secondary hair follicles that are in different stages of the hair cycle at any one time (Scott et al., 2000). This fact can cause some morphological differences among hair follicles that reveal themselves also in the connective compartment and in the spatial distribution of dermal cells.

Since dog hair types vary greatly, we selected only dogs with smooth coats, avoiding curly coats, to standardize our work plan. As it is known (Scott et al., 2000), straight hairs are produced by straight follicles while curly hairs are produced by curly follicles. On the basis of this consideration, we chose only smooth coats to obtain whole longitudinal sections of the cut hair follicles and to observe, at the same time, the entire structure and morphology of the organ.

As we did not want to evaluate age differences, we chose a group of animals whose ages ranged from three to nine years. We retain that this group is homogeneous enough because in this period the dog is considered an adult at the height of its physical and sexual development. We did not select younger or older dogs.

We first carried out morphological investigations on dermal sheath anagen hair follicles and evidenced a structure with typical characteristics as described by other authors (Scott et al., 2000; VonTscharner and Suter, 1994; Jahoda et al., 1992). We identified DS as a thin structure closely adjacent to the outer root sheath and rich in dermal flat cells. By transmission electron microscopy, we observed slender and attenuated cells located among bundles of collagen fibres and parallely aligned to the follicular wall; the whole structure formed a close and continuous sleeve around the anagen hair follicle. The cells presented a typical fibroblastic morphology that is also described in anagen VI mouse hair follicles (Tobin et al., 2003).
The nuclei were rather euchromatic and had a regular and elongated shape. Our observation evidenced a cell population with a uniform appearance.

Immunohistochemical investigation allowed us to evidence CD90 expression in dog skin: the protein was expressed only in the cells with a mesenchymal origin while all epithelial structures resulted negative. Most of the positive cells were located in the perifollicular DS of anagen hair follicles, especially in the bulbar and the soprabulbar regions; despite this, in the dermal papilla there were no cells positive to CD90. Also the infundubulum and the isthmus were negative: the positivity sometimes stopped in a rather sharp way between the isthmic and the soprabulbar region; however, we could sometimes observe positive cells in the lower part of the isthmus. We ascribed these differences to the changeable morphological features of hair follicles (Scott et al., 2000). We also observed clear positivity to CD90 antigen in the endothelial cells of the vascular structures localized in the dermis. As it is known, CD90 protein promotes the adhesion of leukocytes and monocytes to activated endothelial cells during the inflammatory process (Wetzel et al., 2004; Saalbach et al., 2000). However, this protein was also detected on microvascular endothelial cells of noninflamed human skin by immunohistochemical technique (Mason et al., 1996; Fivenson et al., 1992). CD90 was evidenced on endothelial cells of human fetal liver as well (Masson et al., 2006).

Immunocytochemical investigation gave the same pattern of CD90 localization in anagen hair follicles as immunohistochemical technique. CD90 was localized in the dermal cells at the cytoplasmic membrane level. It was distributed all along the cell with a focal expression that is a typical pattern of distribution of the membrane proteins. The immunohistochemical investigation showed CD90 positivity as a continuous line around the hair follicle, while the more accurate immunocytochemical observation revealed a focal expression of the protein.

The precise biological function of CD90 protein is not yet clear (Mansour Haeryfar, 2004); it probably has a complex role in multiple biological processes (Rege and Hagood, 2006). Even if CD90 is considered a marker of mesenchymal stem cells, it is expressed by several kinds of cells including fibroblasts. It is known that these cells exhibit func- 
tional and phenotypic heterogeneity among organs and also within tissues (Silvera et al., 1991; Jordana et al., 1988; Elias et al., 1987; Azzarone and Macieira-Coelho, 1982), and that they have a role beyond architectural support. On the basis of CD90 expression, the fibroblasts of some tissues were divided into groups with different morphological and functional characteristics (Koumas et al., 2001, 2003; Borrello and Phipps, 1996; Smith et al., 1995; Derdak et al., 1992). Furthermore it has been hypothesized that $\mathrm{CD}^{+} 0^{+}$fibroblasts are actively involved in wound healing (Koumas et al., 2001, 2003).

On the basis of these considerations, we retain that the clear localization of $\mathrm{CD} 90^{+}$cells we noted in dog skin specimens is of some interest, and suppose that this result may provide further evidence for biological differences existing among mesenchymal cells of the dermis. The lower part of anagen hair follicles is the only region where $\mathrm{CD} 90^{+}$cells are localized while the dermal sheath cells of the upper hair follicle, such as the mesenchymal cells scattered in the dermis, result CD90. The localization is so specific that CD90 may also be considered as being a marker of this region.

Some authors have recently described the multilineage differentiation potential of fibroblasts and their homology with mesenchymal stem cells (Lorenz et al., 2008; Lysy et al., 2007; Chen et al., 2007). They observed that skin fibroblasts are able to differentiate towards mesodermal and endodermal lineages, and provide arguments that these cells share mesenchymal stem cells features both at phenotypic and functional levels.

The CD90 positive area is included among the regions where cells with stem characteristics and with a regenerative capacity towards an amputated bulb reside, as described in the literature (Hoogduijn et al., 2006; McElwee et al., 2003; Jahoda et al., 2003; Lako et al., 2002). For this reason we suppose that the $\mathrm{CD}^{2} 0^{+}$population likely includes stem cells. However, the area we observed was quite large with regard to hair follicle extension and it is probable that a $\mathrm{CD} 90^{+}$population may comprise other kinds of cells such as progenitor and endothelial cells. Furthermore, to support our hypothesis, it is important to point out that the dermal papilla cells are the only CD90 cells in the lower part of the anagen hair follicle. A migration of cells from the dermal sheath to the papilla during anagen has been described and it has been hypothesized that dermal papilla cells derive from dermal sheath cells (Tobin et al., 2003). Even if they share the same mesenchymal origin, the immunohistochemical differences we observed allowed us to distinguish the two cell populations; they may present distinct functions and may be sited at two different levels of differentiation.

As described by other authors, the division of stem cells gives rise to a hierarchy of cells gradually moving outside the stem compartment, and showing a progressive reduction of proliferative and differentiation potential (Taylor et al., 2000). This may be the role of the $\mathrm{CD} 90^{+}$dermal sheath cells and the CD90 negative dermal papilla cells respectively.

\section{Acknowledgments}

The authors wish to thank Mrs. Gabriella Mancini and Mrs. Paola Coliolo for their excellent technical assistance.

\section{References}

Azzarone B, Macieira-Coelho A. Heterogeneity of the kinetics of proliferation within human skin fibroblastic cell populations. J Cell Sci 1982;57:177-187.

Borrello MA, Phipps RP. Differential Thy-1 expression by splenic fibroblasts defines functionally distinct subsets. Cell Immunol 1996; 173:198-206.

Chen FG, Zhang WJ, Bi D, Liu W, Wei X, Chen FF. Clonal analysis of nestin- vimentin+ multipotent fibroblasts isolated from human dermis. J Cell Sci 2007;120: 2875-83.

Cotsarelis G, Sun TT, Lavker RM. Label-retaining cells reside in the bulge area of pilosebaceous unit: implications for follicular stem cells, hair cycle, and skin carcinogenesis. Cell 1990;61:1329-37.

Craig W, Kay R, Cutler RL, Lansdorp PM. Expression of Thy-1 on Human Hematopoietic Progenitor Cells J Exp Med 1993;177: 1331-42.

Derdak S, Penney DP, Keng P, Felch ME, Brown D, Phipps RP. Differential collagen and fibronectin production by Thy $1+$ and Thy 1- lung fibroblast subpopulations. Am J Physiol 1992;263:L283L290.

Elias JA, Rossman MD, Phillips PD. Phenotypic variability among density-fractionated human lung fibroblasts. Am Rev Respir Dis 1987; 135:57-61

Erices $\mathrm{A}$, Conget $\mathrm{P}$, Minguell J. Mesenchymal progenitor cells in human umbilical cord blood. Br J Haematol 2000;109:235-42.

Fivenson DP, Douglass MC, Nickolofft BJ. Cutaneous expression of Thy-1 in mycosis fungoides. Am J Path 1992;141:1373-80.

Gharzi A, Reynolds AJ, Jahoda CA. Plasticity of hair follicle dermal cells in wound healing and induction. Exper Dermat 2003;12:12636.

Haeryfar SM, Hoskin DW. Thy-1: more than a mouse pan-T cell marker. J Immunol 2004;173:3581-8.

Hoogduijn MJ, Gorjup E, Genever PG. Comparative characterization of hair follicle dermal stem cells and bone marrow mesenchymal stem cells. Stem Cells Dev 2006;15:49-60.

In 't Anker PS, Scherjon SA, Kleijburg-van der Keur C, Noort WA, Claas FH, Willemze R, et al. Amniotic fluid as a novel source of mesenchymal stem cells for therapeutic transplantation. Blood 2003;102:1548-9. 
Jahoda CA, Mauger A, Bard S, Sengel P. Changes in fibronectin laminin and type IV collagen distribution relate to basement membrane restructuring during the rat vibrissa follicle hair growth cycle. J Anat 1992;181:47-60.

Jahoda CA, Reynolds AJ. Hair follicle dermal sheath cells: unsung participants in wound healing. Lancet 2001;358:1445-48.

Jahoda CA, Whitehouse CJ, Reynolds AJ, Hole N. Hair follicle dermal cells differentiate into adipogenic and osteogenic lineages. Exp Dermatol 2003;12:849-59.

Jahoda CA. Cell movement in the hair follicle dermis - more than a two-way street? J Invest Dermatol 2003;121:ix-xi.

Jordana M, Schulman J, McSharry C, Irving LB, Newhouse MT, Jordana $G$, et al. Heterogeneous proliferative characteristics of human adult lung fibroblast lines and clonally derived fibroblasts from control and fibrotic tissue. Am Rev Respir Dis 1988;137:57984.

Kemshead JT, Ritter MA, Cotmore SF, Greaves MF. Human Thy-1: expression on the cell surface of neuronal and glial cells. Brain Res 1982;236:451-61.

Kern S, Eichler H, Stoeve J, Klüter $\mathrm{H}$, Bieback K. Comparative analysis of mesenchymal stem cells from bone marrow, umbilical cord blood, or adipose tissue. Stem Cell 2006;24:1294-301.

Korn JH, Torres D, Downie E. Clonal heterogeneity in the fibroblast response to mononuclear cell derived mediators. Arthritis Rheum 1984;27:174-9.

Koumas L, King AE, Critchley HO, Kelly RW, Phipps RP. Fibroblast heterogeneity. existence of functionally distinct Thy $1+$ and Thy 1 human female reproductive tract fibroblasts. Am J Pathol 2001 159:925-35.

Koumas L, Smith TJ, Feldon S, Blumberg N, Phipps RP. Thy-1 expression in human fibroblast subsets defines myofibroblastic or lipofibroblastic phenotypes. Am J Pathol 2003;163:1291-300.

Lako M, Armstrong L, Cairns PM, Harris S, Hole N, Jahoda CA. Hair follicle dermal cells repopulate the mouse haematopoietic system. Cell Sci 2002;115:3967-74.

Le Blanc K, Ringden 0. Mesenchymal stem cells: properties and role in clinical bone marrow transplantation. Curr Opinion in Immun 2006 18:586-91.

Lysy PA, Smets F, Sibille C, Najimi M, Sokal EM. Human skin fibroblasts: from mesodermal to hepatocyte-like differentiation. Hepatol 2007;46:1574-85.

Lorenz K, Sicker M, Schmelzer E, Rupf T, Salvetter J, SchulzSiegmund M. Multilineage differentiation potential of human dermal skin-derived fibroblasts. Exper Dermat 2008;17:925-32.

Low MG, Kincade PW. Phosphatidylinositol is the membrane-anchoring domain of the Thy-1 glycoprotein. Nature 1985;318:62-4.

Lyle $\mathrm{S}$, Christofidou-Solomidou M, Liu $\mathrm{Y}$, Elder DE, Albelda $\mathrm{S}$, Cotsarelis $\mathrm{G}$. The C8/144B monoclonal antibody recognizes cytokeratin 15 and defines the location of human hair follicle stem cells. J Cell Sci 1998;111:3179-88.

Mansour Haeryfar SM, Hoskin DW. Thy-1: More than a Mouse Pan-T Cell Marker J Immunol 2004;173:3581-8.

Mason JC, Yarwood H, Tarnok A, Sugars K, Harrison AA, Robinson PJ et al. Human Thy-1 is cytokine-inducible on vascular endothelia cells and is a signaling molecule regulated by protein kinase $\mathrm{C}$. J Immunol 1996;157:874-83.

Masson NM, Currie IS, Terrace JD, Garden 0J, Parks RW, Ross JA. Hepatic progenitor cells in human fetal liver express the oval cel marker Thy-1. Am J Physiol Gastrointest Liver Physiol 2006;291: G45-54

McElwee KJ, Kissling S, Wenzel E, Huth A, Hoffmann R. Cultured peribulbar dermal sheath cells can induce hair follicle development and contribute to the dermal sheath and dermal papilla. J Invest Dermatol 2003:121:1267-75.

McKenzie JL, Fabre JW. Human thy-1 : unusual localization and possible functional significance in lymphotd tissues. J Immun 1981; 126:843-50.

Mercati F, Pascucci L, Gargiulo AM, Dall'Aglio C, Ceccarelli P. Immunoistochemical evaluation of intermediate filament nestin in dog hair follicles. Histol Histopathol 2008;23:1035-41.

Morris R. Thy-1 in developing nervous tissue. Dev Neurosci 1985;7: 133-60.
MuAoz-Fernandez $R$, Blanco $F$, Frecha $C$, Martìn F, Kimatrai M, Abadì-Molina $A C$, et al. Follicular dendritic cells are related to bone marrow stromal cell progenitors and to myofibroblasts. J Immunol 2006;177:280-9.

Nakamura Y, Muguruma Y, Yahata T, Miyatake H, Sakai D, Mochida J, et al. Expression of CD90 on keratinocyte stem/progenitor cells. Brit J Dermatol 2006;154:1062-70.

Narisawa-Saito M, Yamanashi Y, Morioka T, Oite T, Shimizu F. Thy-1 molecule associates with protein tyrosine kinase(s) in rat mesangial cells. Clin Exp Immunol 1996;106:86-90.

O'Donoghue K, Choolani M, Chan J, de la Fuente J, Kumar S, Campagnoli $\mathrm{C}$, et al. Identification of fetal mesenchymal stem cells in maternal blood: implications for non-invasive prenatal diagnosis. Mol Hum Reprod 2003;9:497-502.

Pascucci L, Mercati F, Gargiulo AM, Pedini V, Sorbolini S, Ceccarelli P. CD34 glycoprotein identifies putative stem cells located in the isthmic region of canine hair follicles. Vet Dermat 2006;17:244-51.

Phipps RP, Penney DP, Keng P, Quill H, Paxhia A, Derdak S, et al. Characterization of two major populations of lung fibroblasts: distinguishing morphology and discordant display of Thy 1 and class II MHC. Am J Respir Cell Mol Biol 1989;1:65-74.

Pittenger MF, Mackay AM, Beck SC, Jaiswal RK, Douglas R, Mosca JD, et al. Multilineage potential of adult human mesenchymal stem cells. Science1999;284:143-7.

Rege TA, Hagood JS. Thy-1 as a regulator of cell-cell and cell-matrix interactions in axon regeneration, apoptosis, adhesion, migration, cancer, and fibrosis. FASEB J 2006;20:1045-54.

Saalbach A, Haustein UF, Anderegg U. A ligand of human Thy- 1 is localized on polymorphonuclear leukocytes and monocytes and mediates the binding to activated Thy-1-positive microvascular endothelial cells and fibroblasts. J Invest Dermatol 2000;115:882-

Schneider MR, Schmidt-Ullrich R, Paus R. The hair follicle as a dynamic miniorgan. Curr Biol 2009;19:R132-R142.

Scott DW, Muller WH, Griffin CE. Muller and Kirk's small animal dermatology. 6th edition" Saunders, Philadelphia, 2000.

Shi S, Gronthos S. Perivascular niche of postnatal mesenchymal stem cells in human bone marrow and dental pulp. J Bone Miner Res 2003; 18:696-704.

Silvera MR, Derdak S, Penney DP, Keng PC, Phipps RP. Differential expression of interleukin 1 receptors by murine lung fibroblast subpopulations: role of pro-inflammatory interleukin 1 in stimulating fibroblast proliferation and collagen synthesis. Life Sci Adv Immunol 1991;10:21-8

Smith TJ, Sempowski GD, Wang HS, Del Vecchio PJ, Lippe SD, Phipps RP. Evidence for cellular heterogeneity in primary cultures of human orbital fibroblasts. J Clin Endocrinol Metab 1995;80:2620-5.

Taylor G, Lehrer MS, Jensen PJ, Sun TT, Lavker RM. Involvement of follicular stem cells in forming not only the follicle but also the epidermis. Cell 2000;102:451-61.

Tobin DJ, Gunin A, Magerl M, Handijski B, Paus R. Plasticity and cytokinetic dynamics of the hair follicle mesenchyme: implications for hair growth control. J Invest Dermatol 2003;120:895-904.

Tokugawa Y, Koyama M, Silver J. A molecular basis for species differences in Thy-1 expression patterns. Mol Immunol 1997;34:126372.

Von Tscharner C, Suter MM. Morphology and function of the hair follicle. Proc. 11th ESVD congress, Bordeaux; 1994.

Wetzel A, Chavakis T, Preissner KT, Sticherling M, Haustein UF, Anderegg $U$, et al. Human Thy-1 (CD90) on activated endothelial cells is a counterreceptor for the leukocyte integrin Mac-1 (CD11b/CD18). J Immunol 2004;172:3850-9.

Yoshimura K, Shigeura T, Matsumoto D, Sato T, Takaki Y, Aiba-Kojima $E$, et al. Characterization of freshly isolated and cultured cells derived from the fatty and fluid portions of liposuction aspirates. $J$ Cell Physiol 2006;208:64-76.

Zhang $Y$, Xiang $M$, Wang $Y$, Yan J, Zeng $Y, Y u$ J, et al. Bulge cells of human hair follicles: segregation, cultivation and properties. Colloids Surf B Biointerfaces 2006;47:50-6.

Zuk PA, Zhu M, Ashjian P, De Ugarte DA, Huang JI, Mizuno H, et al. Human adipose tissue is a source of multipotent stem cells. Mol Biol Cell 2002; 13:4279-95. 